\title{
EXPLORAÇÃO DA TERRA E DO TRABALHO NA FRONTEIRA AGROPECUÁRIA DA AMAZÔNIA ORIENTAL: O CASO DE SÃO FÉLIX DO XINGU (PA)
}

\section{Sebastião Novais Sousa Crispim ${ }^{1}$ Giancarlo Livman Frabetti²}

\section{INTRODUÇÃO}

No Estado do Pará o agronegócio se organiza em três eixos principais: a soja, o dendê e a pecuária. Dessas três atividades, é a pecuária quem dinamiza de forma mais importante a economia estadual. Seu desenvolvimento se dá com maior vulto na mesorregião Sudeste do Pará, com particular destaque para o município de São Félix do Xingu, o qual comporta o maior rebanho bovino do país, com cerca de 2,2 milhões de cabeças de gado atualmente ${ }^{3}$, além de indústrias frigorificas de grande porte. 0 avanço da bovinocultura nessa porção da Amazônia Oriental deve-se, historicamente, a uma combinação entre dois fatores: de um lado, os programas estatais de fomento à atividade agropecuária, conduzidos durante 0 Regime Militar sob uma finalidade ao mesmo tempo econômica e geopolítica e, de outro lado, à grilagem desenfreada de terras impondo intensa concentração fundiária no processo de avanço da fronteira agropecuária entre as décadas de 1960 e 1990 no Brasil. Cerca de 1/4 da produção de carne bovina originada no Sudeste paraense é destinada ao consumo interno no próprio estado do Pará. O restante é distribuído para outros estados do Brasil (em grande parte o Nordeste) e, mais recentemente, passou a ser exportado no mercado internacional. Com o controle cada vez mais rigoroso de práticas sanitárias e o próprio investimento em tecnologia para buscar o melhoramento genético das raças, o Estado do Pará avançou na garantia do Certificado Internacional de Área Livre Aftosa, o que possibilitou uma abertura em escala ainda maior no mercado internacional. Atualmente, a carne bovina brasileira responde pelo maior participação dentre os países exportadores desse produto no mundo, alcançando sobretudo os mercados de Hong Kong, União Europeia e China.

No entanto, esse aspecto de progresso e modernidade contrasta com o histórico de conflitos que marcam a realidade da mesorregião Sudeste do Pará, sendo este um território marcado por casos de violência contra populações camponesas, ribeirinhas e indígenas, além de ter sido a área de maior

\footnotetext{
${ }^{1}$ Mestre em Economia pelo Programa de Pós-Gradução em Economia/Universidade Federal do Pará. E-mail: crispimns85@gmail.com.

${ }^{2}$ Professor da Faculdade de Economia/UFPa e Doutor em Geografia pela USP (Universidade de São Paulo). Email: giancarlofrabetti@gmail.com.

3 Dado de 2017 da Pesquisa de Produção da Pecuária Municipal, realizada pelo Instituto Brasileiro de Geografia e Estatística (IBGE).
} 
ocorrência de casos de trabalho escravo no Brasil entre os anos de 1995 e 2016, segundo dados da Comissão Pastoral da Terra. $\mathrm{O}$ alto nível de competitividade alcançado pelo setor agropecuário vem, portanto, na esteira de um rastro de violência, expropriação camponesa e superexploração do trabalho, além desta ser a atividade econômica responsável pela maior quantidade das áreas desflorestadas no Sudeste do Pará, o que se dá particularmente a partir do avanço das grandes fazendas de criação de gado para esta região (CARVALHO, 2012). Perguntamos, nesse sentido, em qual medida a modernização da atividade econômica promoveu (ou não) a generalização das condições especificamente capitalistas de produção no que se refere às relações sociais de propriedade e de trabalho na mesorregião Sudeste do Pará.

Portanto, deparamo-nos neste trabalho com o objetivo central de dimensionar 0 nível de exploração da terra e do trabalho nesta área avançada de expansão da fronteira agropecuária na Amazônia Oriental brasileira, em contraposição com a competitividade internacional alcançada pelo setor. Para alcançar tal objetivo, propomos primeiramente reconstituir historicamente o processo de implantação das grandes fazendas agropecuárias no Sudeste do Pará e, em específico, no município de São Félix do Xingu, tendo como perspectiva teórica os processos de acumulação primitiva do capital em sua fase de reprodução ampliada (OLIVEIRA, 1986), bem como o conceito de fronteira, enquanto espaço de (des)encontro entre a frente de expansão e a frente pioneira na Amazônia (MARTINS, 2009). Além disso, para resolver nosso objetivo central, propomos a realização de um levantamento de dados estatísticos a fim de avaliar o nível de concentração da estrutura fundiária e da precarização do trabalho em São Félix do Xingu. O procedimento metodológico de investigação que permitiu a construção da argumentação contida no presente trabalho consiste, primeiramente, na pesquisa bibliográfica de autores que já trataram dos processos históricos e geográficos de avanço da fronteira agropecuária na Amazônia (VELHO, 1974; SCHMINK; WOOD, 2012; MARTINS, 2009; OLIVERIA, 1993). Além disso, realizaremos o levantamento de dados que nos permitam inferir o nível de concentração fundiária e o caráter das relações de trabalho na agropecuária paraense. Para tanto, faremos uso das bases de dados do Instituto Brasileiro de Geografia e Estatística (IBGE), sendo os Censos Demográfico e Agropecuário; de dados socioeconômicos, como o Índice do Desenvolvimento Humano (IDH) que demostram o níveis de renda e desigualdade disponíveis pelo Atlas do Desenvolvimento Humano (PNUD/IPEA); além dos dados e relatórios disponibilizados pela Comissão Pastoral da terra (CPT).

Além desta introdução, o presente trabalho apresenta mais quatro seções: a primeira delas tratará do movimento da frente de expansão na Amazônia. A segunda seção abordará o papel do Estado 
no período do Regime Militar nos projetos de desenvolvimento na Amazônia, particularmente nos projetos agropecuários. Demonstraremos como se deu o avanço da chamada frente pioneira no Sudeste do Pará, compondo, enfim, o cenário de conflitos na fronteira agropecuária da Amazônia Oriental. Na terceira seção expomos os resultados do nosso levantamento de dados e indicadores utilizados para tratar da estrutura fundiária e do mundo do trabalho em nossa área de estudo e, por fim, teceremos nossas considerações finais.

\section{A economia dos castanhais e a frente de expansão no Sul do Pará}

Segundo Michelotti (2009), é possível compreender a história do avanço da fronteira agropecuária no Sudeste do Pará a partir de um recorte em três grandes períodos: a) início do século XX até década de 1960 (caracterizado pela existência de uma frente de expansão da castanha e pecuária); b) 1970 a 1989 (no qual são implantadas as grandes fazendas agropecuárias, com intenso conflito em torno da propriedade da terra); c) 1990 até hoje (período em que as lutas camponesas resultam em Projetos de Assentamentos da Reforma Agrária, bem como se consolida a pecuária bovina de corte).

Com a crise da borracha (1912-1919), "o interior da Amazônia sofreu enorme involução. Em Marabá, no entanto, a elite local de comerciantes conseguiu reestruturar a atividade produtiva, substituindo-a pela exploração da castanha", tonando-se Marabá o principal centro dessa produção (MICHELOTTI, 2009, p.248). Sendo assim, até meados do século XX, a então chamada região Sul do Estado do Pará tinha como principal atividade econômica a coleta da castanha e da borracha, e os sujeitos sociais ali representados eram, sobretudo, indígenas, camponeses posseiros e as oligarquias latifundiárias.

O método utilizado para garantir a reprodução capitalista durante esse período foi o sistema de aviamento, forma de exploração da mão de obra que foi consolidada no período da borracha em meio aos barracões nas florestas. Leal (2010, p.104-105) define essa modalidade como "um sistema de financiamento no qual cada degrau, no sentido descendente, significava um grau de dureza a mais para quem estivesse situado na parte inferior, devedora". O trabalhador se amarrava a um endividamento antecipado que, contudo, apenas lhe proporcionava o básico para sua sobrevivência, de modo a fazê-lo permanentemente voltar à mata para coletar os bens que lhe permitiam inserção nesta economia monetária ainda incipiente.

Devido à grande disponibilidade de terras, sobretudo no interior dessa região, seu valor no mercado se dava prioritariamente de acordo com a concentração de espécies vegetais que permitiam a 
coleta, para posterior conversão monetária do produto (IANNI, 1981). O caráter livre da posse da terra, sobretudo adentrando-se o vasto interior da floresta, dava margem para que viessem a ocorrer uma série de levas migratórias de outros Estados do Brasil para esta região, compostas por populações camponesas empobrecidas - formadas por posseiros, pequenos proprietários e meeiros originários, em primeiro momento, principalmente do Estado do Maranhão (BECKER, 2015).

Quando o Estado busca incentivar a migração desse contingente populacional do Nordeste para a Amazônia, o que de fato ele realiza é a transferência do conflito de outras regiões para a nova fronteira do capital. Esse fluxo cada vez maior de migrantes para região passou a ocupar, já na primeira metade do século XX, as terras de Conceição do Araguaia e de grande parte de toda região Sul do Pará. Para Velho (1974) a formação de um campesinato foi um dos traços do desenvolvimento capitalista na Amazônia. Esse campesinato se organizou de formas diversas, mas em grande parte era migrante, oriundo de outras partes do Brasil, que buscou adaptar-se às condições da Amazônia através do convívio violento com as populações indígenas, mas também com as antigas oligarquias da borracha e dos castanhais.

Segundo Velho (1974), a partir da segunda metade do século XX, com modificações ocorridas na lei de aforamento dos castanhais, surgiu a possibilidade do seu arrendamento perpétuo. Com isso, aumentaram os investimentos nas benfeitorias dos castanhais, bem como se ampliou a criação de gado associado ao extrativismo da castanha, embora, até a década de 60 , essa produção servisse basicamente ao abastecimento do mercado local, sendo eventualmente comercializada em Belém. Esse campesinato tinha como principal forma de produção uma agricultura caracteristicamente de subsistência, tendo sua inserção na economia monetária intermediada pela eventual venda da castanha. Havia dificuldade para essas frentes migratórias de camponeses se estabelecerem em Marabá, já que lá "as terras já eram cada vez mais amplamente ocupadas pelos castanhais associados a pecuária. Por isso, esta frente tendeu a se situar nos municípios menores e mais afastados como São João do Araguaia e Itupiranga" (MICHELOTTI, 2009, p. 248).

Tal campesinato foi fundamental para a incorporação de novas áreas para se tornarem posteriormente agricultáveis, com o crescimento rápido do município de Marabá e de atividades agrícolas no lugar do extrativismo tradicional. Além disso, esse campesinato teve papel importante na integração de áreas ainda inexploradas da região, sendo os rios os seus principais meios de penetração do território, tornando assim, a ocupação do interior da região possível antes mesmo das chegadas das estradas. 
Paulatinamente o comércio crescia, o que possibilitou, a formação de um mercado interno na região. Desenvolve-se, assim, uma nova forma de articulação do campesinato que chegava. Para além das atividades agrícolas e extrativistas, alguns desses migrantes vieram também a se tornar comerciantes, formando uma espécie de classe intermediária. A produção camponesa estava cada vez mais dependente da estrutura estabelecida nos créditos dos comerciantes. Existe aqui uma contradição nessas relações entre comerciantes e camponeses, ambos de certa forma são dependentes entre si.

\begin{abstract}
No meu modo de ver, as relações sociais (e de produção) na frente de expansão são predominantemente relações não capitalistas de produção mediadoras da reprodução capitalista do capital. Isso não faz delas outro modo de produção. Apenas indica uma insuficiente constituição dos mecanismos de reprodução capitalistas na frente de expansão. Insuficiência que decorre de situações em que a distância dos mercados e a precariedade das vias e meios de comunicação comprometem a taxa de lucro de eventuais empreendedores. Portanto, aí tendem a se desenvolver atividades econômicas em que não assumem forma nem a realidade própria os diferentes componentes da produção propriamente capitalista, com 0 salário, o capital e a renda da terra. Os meios de produção ainda não aparecem na realidade da produção como capital nem a força de trabalho chega a se configurar na categoria salário (MARTINS, 2012, p.156).
\end{abstract}

Essa chamada frente de expansão, que incidiu sobre a então denominada região Sul do Pará, viria a encontrar sua antítese a partir de uma série de eventos que passariam a modificar o cenário dos tempos lentos vividos pelas populações de camponeses, ribeirinhos e das antigas elites oligarcas nesta região. A partir da década de 1970, os grandes projetos de desenvolvimento financiados e conduzidos pelo Estado autoritário característico de uma ditadura militar passaram a criar e intensificar conflitos, bem como dissolver antigas relações na mesma medida em que se dava o avanço das grandes fazendas de criação de gado sobre este território.

\title{
2. Os grandes projetos de desenvolvimento na Amazônia e a chegada da frente pioneira
}

A partir da década de 1960, grandes projetos econômicos combinados com ação institucional do governo federal busca organizar uma nova etapa de transformação das relações sociais na Amazônia, onde uma nova elite é incentivada a se estabelecer em detrimento das antigas elites oligárquicas. Estes novos sujeitos que entram em cena são representados principalmente pelas empresas agropecuárias com capital nacional oriundas do Centro-Sul. Incentivados pelo governo federal através de credito barato e pela a criação de órgãos públicos como a Superintendência de Desenvolvimento da Amazônia (SUDAM), com promoção de incentivos fiscais, estrutura urbana e rodoviária, estes grandes fazendeiros 
protagonizaram a formação de um mercado terras com base na grilagem e na violência, marcando definitivamente a história e a geografia desta região do Sudeste do Pará.

A Amazônia teve um papel duplamente estratégico para os governos militares que se sucederam no poder federal brasileiro a partir do golpe de 1964: com um vasto território que abrange praticamente a metade do Brasil, a região Norte por ser considerada ideal para absorver investimentos de capital e 0 excedente de mão de obra de outras partes do Brasil; além disso, sob a perspectiva desses governos, impunha-se a tarefa de garantir a soberania nacional sobre este vasto território, então considerado ideologicamente como um "vazio demográfico".

Industrializar, a qualquer custo, parecia ser o único caminho para trazer a Amazônia ao século XX, ou emancipá-la dos males do extrativismo: surtos de expansão, crise e regressão; dispersão das fontes de matérias-primas: borracha, castanha, madeira, peles, minerais, etc.; o "vazio demográfico" e o "vazio econômico" que povoam os discursos de governantes locais, regionais; 0 despovoado das muitas fronteiras do Brasil com o Peru, Equador, Colômbia, Venezuela, Guianas, etc. (IANNI, 1979, p. 62).

Sendo assim, a região amazônica teve um papel estratégico tanto do ponto de vista geopolítico, quanto do ponto de vista econômico. Incorporar terra barata e abundante ao capital era fator de impulso do projeto de desenvolvimento. Essa etapa da expansão da fronteira do capitalismo foi comandada pelo Estado, tendo vigência entre 1966 e 1980, e desencadeou a criação de uma série de instrumentos institucionais, bem como obras de infraestrutura para atrair colonos e grandes projetos de desenvolvimento. Dentre esses grandes projetos, destaca-se, no sudeste do Pará, o Projeto Grande Carajás, executado pela então estatal Companhia Vale do Rio Doce, voltado à extração de minério de ferro com grande grau de pureza, além de produzir carvão para as siderúrgicas e de atrair grandes empresas investidoras do setor agropecuário. Além disso, o Estado também se encarregou da abertura de importantes rodovias, reforçando a integração da Amazônia ao restante do país, tendo este movimento se iniciado pela construção da rodovia Belém-Brasília na década de 1950, e continuado com a abertura da rodovia Transamazônica e da BR-222, que serviram de corredores para os projetos de colonização oficial, atraindo enormes contingentes populacionais que migravam, principalmente, do nordeste, sudeste e sul do Brasil.

Cabe notar que no ano mesmo de 1964, em que se dá o golpe militar que destitui João Goulart, é promulgado o Estatuto da Terra, instrumento que também se voltou para o objetivo de arrefecer as lutas no campo e as reivindicações por reforma agrária, por meio do pressuposto da função social da terra, sem, contudo, promover a expropriação dos latifúndios. Passaria, então, a ocorrer a transferência de poder das antigas oligarquias para uma nova classe de proprietários de terra, estabelecida por meio 
de decretos unilaterais que foram emitidos em Brasília e impostos aos antigos mandatários da região (SCHMINK; WOOD, 2012).

Os governos militares passaram a adotar uma série de medidas políticas/econômicas para desenvolver o país segundo a mencionada dupla estratégia pensada para a Amazônia (econômica e geopolítica a uma só vez). A modernização econômica passa a se dar por meio de incentivos fiscais, destacando-se, nesse sentido, a criação da SUDAM em 1966, que substitui a Superintendência do Plano de Valorização Econômica da Amazônia (SPVEA), a partir de cuja criação se abriu caminho para o aporte de capitais do Centro-Sul na região Norte, contando com estes incentivos fiscais. A SUDAM se notabilizou por ser o órgão executor dos programas do governo federal, atraindo empreendedores de outras regiões do Brasil para investir na Amazônia.

Também foi introduzida, nesse contexto, a Operação Amazônia, que ofertava incentivos fiscais generosos financiados pelo Banco da Amazônia (Basa). Durante a década 1970, cerca de um bilhão de dólares foram investidos na agropecuária na Amazônia, sendo o setor madeireiro o segundo a captar mais recursos junto a SUDAM. É possível, portanto, afirmar que o Estado e as empresas de capital privado estabeleceram uma aliança nesse processo de intensificação da ocupação da Amazônia (IANNI, 1979). Nesse sentido todo o aparato criado e suas instituições estavam a serviço para beneficiar estas empresas, com os bancos públicos emprestando dinheiro a juros muito baixos para potenciais investidores na região. Estes empresários agropecuários justificavam seus investimentos mediante a retorica de desenvolver a região e integra-la ao Brasil moderno e ao próprio capitalismo.

Muitas foram as promessas feitas pelos pecuaristas da Amazônia (que se organizaram na "Associação dos Empresários Agropecuários da Amazônia"), dentre elas aquela de que, com os projetos agropecuários, Belém seria transformada no maior porto exportador de carne do mundo, superando, pois Chicago-EUA (OLIVEIRA, 1993, p.67).

Esse empresariado de origem principalmente no Centro-Sul do Brasil optou pela implantação da pecuária como a principal atividade econômica, realizando inversões de capital muito lucrativas pelo mecanismo dos incentivos fiscais. Este processo de expansão da pecuária extensiva configurou um movimento de penetração das fazendas de criação de gado pelo interior do país. A criação extensiva de gado nelore "oportuniza as terras baratas ou sem custos de aquisição nas fronteiras, a fertilidade natural dessas terras, o baixo custo de mão de obra e, principalmente, o espaço pouco ocupado" (CASTRO; MONTEIRO; CASTRO, 2004, p.24). Por conta disso, em um movimento vai adentrando o interior do país pelo Centro-Oeste, Norte do Mato Grosso e Sul do Pará, conforme as terras mais bem localizadas vão ficando mais caras, eleva-se o custo de reforma dos pastos, tornando essas terras menos rentáveis para 
o gado de corte. Martins (2012) analisa o (des)encontro entre sujeitos sociais nessas áreas de expansão das fazendas de gado, a partir da diversidade de relações sociais que acompanham o avanço capitalista na agropecuária. Dessa forma, o autor utiliza o conceito de fronteira para analisar a sociedade e suas temporalidades históricas, sendo que a fronteira é concebida como o lugar da alteridade. 0 conflito é a forma mais evidente desta forma socioespacial:

O desencontro de perspectivas é, nesse caso, essencialmente expressão da contraditória diversidade da fronteira, mais do produto da diversidade de pontos de vistas sobre fronteira. Diversidade que é, sobretudo, diversidade de relações sociais marcadas por tempos históricos diversos e, ao mesmo tempo, contemporâneos (MARTINS, 2012, p. 137).

Martins (2012) interpreta a fronteira a partir da distinção entre a frente pioneira (de caráter econômico) e a frente de expansão (de caráter antropológico), articulando-as para compreender este fenômeno como comportando o lugar e tempo de conflito e de alteridade. A frente de expansão e a frente pioneira podem ser compreendidas como a espacialidade da expansão e da reprodução do capital, sendo que a frente de expansão coincide com as formas não especificamente capitalistas de produção (posse da terra, economia pouco monetizada), enquanto a frente pioneira corresponde à fase de reprodução ampliada do capital (com a consolidação da propriedade privada da terra e a instauração de uma economia propriamente de mercado).

Quem conhece a fronteira sabe perfeitamente que nela, de fato, essas "faixas" se mesclam, se interpenetram, pondo em contato conflitivo populações cujos antagonismos incluem 0 desencontro dos tempos históricos em que vivem. A recente expansão da fronteira mostrou isso de maneira muito clara. Práticas de violência nas relações de trabalho, como a escravidão por dívida, próprias da história da frente de expansão, são adotadas sem dificuldades por modernas empresas da frente pioneira. Pobres povoados camponeses da frente expansão permanecem ao lado de fazendas de grandes grupos econômicos, equipadas com o que de mais moderno existe em termo de tecnologia (MARTINS, 2012, p. 149).

A fronteira dessa forma avança pela mata, derrubando florestas e expropriando a pequena agricultura familiar. Portanto, a uma aceleração do avanço da fronteira o que obriga o deslocamento da frente de expansão, e com isso, emerge violentamente o conflito entre camponeses posseiros e os grandes proprietários de terra. Os camponeses cada vez mais se veem forçados a migrarem para outras terras ou a venderem sua força de trabalho de forma sazonal. A posse da terra entrava em disputa, de modo que, conforme uma área fosse introduzida no avanço estruturante que o Estado implantou na Amazônia, com a construção de rodovias e a instalação de grandes projetos, os migrantes e camponeses partiam para novas áreas ocupando e tomando posse de pequenos lotes de terra. Não obstante, os empresários ou grandes grupos econômicos, que em sua maioria tinham o interesse em ter a terra para finalidade puramente especulativa, acabavam comprando as mesmas terras através de articulações com 
órgãos responsáveis pela regularização fundiária em Brasília e Belém. No caso específico do Sudeste do Pará, a abertura das rodovias significou uma forma de ligação que sobrepujou a antiga forma, que se dava pela via fluvial por Imperatriz. Segundo Michelotti (2009), a região passou a ser ocupada por três estratos distintos: a) os lavradores da frente maranhense; b) os médios fazendeiros conhecidos como "baianos"; c) os grandes fazendeiros de fora e também de Marabá, apoiados com crédito da SUDAM. Conforme se instalavam os médios e grandes fazendeiros, a frente maranhense passava a se adentrar cada vez mais para o interior. A valorização fundiária por causa da implantação das rodovias abriu caminho para o processo de grilagem dessas terras.

\begin{abstract}
As referências sobre o processo de grilagem, por vários atores, e as denúncias feitas sobre essa região no Ministério Público, na Política Federal e no IBAMA, confirmam a grilagem (tiragem de terra, para alguns) em SFX e na região do rio Iriri. O "tirador" vende para potencial comprador. Segundo fazendeiros, essa operação não tem nenhum perigo, nem mesmo de perda da terra porque a terra é do estado, e "se é da União é de todos nós". Há uma especialização, de pessoas que só vivem do comércio de terras, mas de certa forma muitos atores sociais estão envolvidos na "tiragem" da terra e em todos os procedimentos que envolvem a sua comercialização. Nessa economia, quem ganha mais é aquele que grila e vende a terra, ou aqueles que compram a terra de grileiros por um preço baixo e que tem capacidade de comercializar os lotes em regiões mais capitalizadas. Quanto à rentabilidade, é superior ao comércio de gado, pois o mercado também é mais aquecido (CASTRO; MONTEIRO; CASTRO, 2004, p.22).
\end{abstract}

Dessa forma a violência tornou-se a mediadora das relações sociais entre Estado, grupos econômicos, elites locais e pequenos proprietários. Outro ponto importante era que parte significativa de policiais, juízes e outras entidades do Estado na região sudeste paraense acabavam por ceder e mesmo se submeter aos interesses dos grupos econômicos e fazendeiros locais. Não dando o mesmo peso e acompanhamento em diversos atos de violência que ocorreram na região, fato esse que até os dias atuais ainda faz parte da realidade no sudeste paraense.

No final da década de 1970, o General Figueiredo solicitou ao Conselho de Segurança Nacional que realizasse estudos para viabilizar medidas para lidar com avanço da escalada da violência na região sudeste paraense, em especial na região ao longo dos rios Araguaia e Tocantins. Nesse sentido, em 1980, foi criado o Grupo Executivo das Terras do Araguaia-Tocantins (GETAT). Um dos objetivos fundamentais era conter a crescente oposição às políticas do governo militar na região, lembrando que esta foi a região ocorreu um dos movimentos de resistência ao regime militar mais contundentes, a guerrilha do Araguaia. O GETAT teve um papel importante no controle dos conflitos ao longo dos anos 1980, contudo, o poder do mercado de terras passou a reger cada vez mais a tendência continuada rumo à concentração da propriedade de terras na fronteira (SCHIMINK; WOOD, 2012). 
Uma nova onda de investidas do governo militar no intuito de fortalecer o controle militar na região foi adotada como a criação, em 1982, do Programa Nacional de Politicas Fundiárias (PNPF) e do Ministério Extraordinário para Assuntos Fundiários (Meaf). Dessa forma o Conselho de Segurança Nacional se estabeleceu no comando das políticas agrárias. Com a chegada da democratização, o Meaf buscou impetrar uma campanha política para reprimir o sentimento de antigoverno que se lastreava entre as entidades representativas da sociedade, como o segmento mais progressista da igreja Católica e movimentos políticos de oposição e os movimentos sociais de luta pela terra. A retomada do Incra como principal regulador do processo de regularização fundiária não conseguiu criar um sentimento de confiança e justiça social nos pequenos proprietários. E mesmo os latifundiários não detinham satisfação total com as políticas que foram adotadas desde o GETAT, pois este órgão impôs recortes e algumas limitações às propriedades dos latifundiários.

A partir da década de 1970 se dá o avanço da fronteira para a região de São Felix do Xingu, como resultado da ocupação em Marabá. Os grupos formados predominantemente por goianos, mineiros e paulistas representam as frentes dos anos 80, "interessadas nas atividades de madeira, especificamente exploração do mogno, e da pecuária. O mercado de terras se aquece e a madeira tornase 0 motivo, justificado por todos (pequenos, médios e grandes) de uma retomada do crescimento econômico" (CASTRO; MONTEIRO; CASTRO, 2004, p.7). Também intensificavam-se as levas de migrantes que vinham para trabalhar como peões para as atividades de desmate nas fazendas. Nesse movimento de atração de investimentos em grandes fazendas pecuaristas, dois aspectos de acumulação primitiva são engendrados: incorpora-se terra ao processo do capital, criando por meio da grilagem de terras uma estrutura fundiária altamente concentrada e um quadro social conflituoso; além disso, as populações camponesas empobrecidas são transformadas em potencial força de trabalho para a atividade da pecuária, especialmente no trabalho de formação das pastagens.

Estava em curso uma espécie de "acumulação primitiva", transformando a terra em propriedade privada legalizada e concentrada nas mãos de empresários; transformando os produtores em assalariados e as condições sociais de produção para 0 autoconsumo e 0 comercio em condições de reprodução do capital (IANNI, 1981, p. 233-234).

Os mesmos mecanismos violentos que provocaram a expropriação camponesa nesta região acabam por propiciar os elementos necessários para formação de um mercado de trabalho para a atividade agropecuária. Registra-se que a mão-de-obra permanente em uma fazenda modal de criação de gado está "restrita a um capataz, um vaqueiro, um ajudante de vaqueiro e um tratorista. A mão-deobra temporária é composta de diaristas, que auxiliam nas vacinações, e empreiteiros, que fazem 0 
aceiro de cercas e as roçadas de pastagens" (CORRÊA et. al, 2015, p. 4). Estes últimos trabalhadores volantes são chamados peões de trecho, vivendo entre as periferias das cidades do interior e as fazendas, sendo normalmente agenciados clandestinamente para o trabalho temporário nas grandes propriedades de criação bovina.

Cabe aqui mencionar que, de fato, a linha de frente do avanço da fronteira na Amazônia não era, a princípio, a atividade agropecuária em si mesma. Na primeira fase de abertura das fazendas, se dava também a extração da madeira, de grande valor comercial, já que a preparação das pastagens nas fazendas se faz através da forma em que o trabalhador se encarrega de derrubar a mata, limpar o terreno e plantar o capim (BECKER, 2015, p. 189). É nesta fase que se dá a derrubada e venda da madeira, sendo esta a atividade efetivamente lucrativa (além de garantir a propriedade da terra grilada).

As pessoas que chegam acabam por se instalar e criar uma "legalidade particular", para preencher o vazio da legalidade oficial. Nesse vazio, todos vendem a madeira, de forma clandestina, do pequeno ao grande. A madeira é de longe 0 que mais aquece a economia e permite transferir ganhos para outras atividades como a pecuária. E a produção pecuária pode se fazer pelo trabalho irregular nas fazendas e pela aquisição de novas terras, na ausência de órgãos responsáveis do Estado e da União (CASTRO; MONTEIRO; CASTRO, 2004, p.23).

Posteriormente, a venda da terra supervalorizada se constituía em si mesma como o grande negócio deste processo. "Historicamente, a pecuária, implantada via desmatamento e posterior formação da pastagem, tem sido considerada a atividade agrícola menos onerosa e mais eficiente para assegurar a posse da terra" (DIAS-FILHO, 2010, p. 11), de modo que esta pecuária extremamente extensiva e de baixa produtividade era mantida à custa da expansão das áreas de pastagem nas áreas de vegetação natural (floresta primária ou cerrado) - portanto, o aumento da produtividade na bovinocultura significava imediatamente o aumento da área de florestas derrubadas para a criação de novas pastagens.

Este foi processo, portanto, que converteu investidores do centro-sul em latifundiários no Brasil e reforçou o caráter rentista do desenvolvimento do capitalismo no Brasil (OLIVEIRA, 2007). Registra-se o fato de que, a princípio, a criação de bovinos era uma atividade de pouca rentabilidade, que só se sustentava diante da expropriação sistemática de terras e da exploração da mão-de-obra barata do peão utilizado na derrubada da mata, no plantio das pastagens e erguendo os mourões para a instalação de cercas. Sendo assim, nesta região avançada da fronteira agropecuária, era consenso que só se criava gado "em terra barata, onde se consegue terra de $R \$ 3$ a $R \$ 4$ mil o alqueire (cada alqueire mede 5 
hectares). Em terra de $\mathrm{R} \$ 15$ mil o alqueire, com seis cabeças por alqueire, não vale a pena o capital imobilizado" (CASTRO; MONTEIRO; CASTRO, 2004, p.26).

Embora mais recentemente tenha surgido o discurso de aumento da eficiência técnica na criação de gado de corte, de modo a minimizar o caráter especulativo da atividade (DIAS-FILHO, 2010), fato é que mesmo com melhorias técnicas no manejo do pasto e na criação dos animais, bem como com a implantação de indústrias frigoríficas na região, o resultado desse movimento de expansão da fronteira agrícola no Sudeste do Pará e, particularmente, em São Félix do Xingu, foi uma estrutura fundiária altamente concentrada e a formação de um proletariado rural extremamente precarizado. Na contramão dessa tendência, contudo, vemos a luta camponesa por terra e trabalho emergir desde a década de 1990, constituindo a antítese desse movimento de expansão do grande capital no setor agropecuário. Estas são as questões que trataremos de esmiuçar neste trabalho, dando sequência à nossa linha de argumentação.

\section{Concentração fundiária e trabalho precário em São Félix do Xingu}

O território do atual município de São Félix do Xingu originou-se a partir da emancipação políticoadministrativa em relação ao município de Altamira (anteriormente denominado Xingu), pela Lei Estadual n. ${ }^{\circ} 2.460$, de 29/12/1961. A partir da última divisão territorial estabelecida em 2016, o município passou a ser constituído por 6 distritos: São Félix do Xingu, Sudoeste, Taboca, Vila Ladeira Vermelha, Vila Lindoeste e Vila Nereu.

Como se pode observar a partir dos dados apresentados na Tabela 1, o crescimento demográfico deste município se dá particularmente entre as décadas de 1980 e 1990, bem como de 2000 para 2010, revelando, desta maneira, o movimento de expansão da fronteira agropecuária para esta região (chegando à posição de $17^{\circ}$ município com a maior população do Estado do Pará): "os grupos de migrantes que chegaram provinham de diferentes lugares do país, na grande parte motivados pelo avanço da fronteira e nas oportunidades de terra e de trabalho" (CASTRO; MONTEIRO; CASTRO, 2004, p.18). De acordo com a Diretoria de Pesquisas, Coordenação de População e Indicadores Sociais, Estimativas da População Residente do IBGE, a projeção da população de São Félix do Xingu para o ano de 2018 é 124.763 pessoas. Contudo, cabe assinalar, devido à grande extensão territorial de São Félix do Xingu $\left(84.212,847 \mathrm{~km}^{2}\right)$, o município apresenta uma baixa densidade demográfica $(1,08$ $\left.\mathrm{hab} / \mathrm{km}^{2}\right)$.

Tabela 1- População residente, 1970 a 2010, São Félix do Xingu (PA)

\begin{tabular}{llllll}
\hline SÃO FÉLIX DO XINGU & 1970 & 1980 & 1991 & 2000 & 2010 \\
\hline
\end{tabular}




\begin{tabular}{lccccc}
\hline TOTAL & 2.332 & 4.954 & 24.891 & 34.621 & 91.340 \\
\hline URBANA & 897 & 1.763 & 8.198 & 12.530 & 45.113 \\
\hline RURAL & 1.435 & 3.191 & 16.693 & 22.091 & 46.227 \\
\hline
\end{tabular}

Fonte: Censo demográfico (Sidra/lBGE).

Os dados do Cadastro Central de Empresas (IBGE) para o ano de 2016 indicam que a Renda Média da população de São Félix do Xingu é de 2,2 salários mínimos (24a posição dentre os 144 municípios do Estado do Pará), embora contraste com esse dado o percentual de 44,8\% de sua população vivendo com rendimento nominal mensal per capita de até $1 / 2$ salário mínimo, segundo o Censo Demográfico de 2010 - revelando, com isso, uma profunda desigualdade de renda no município.

Vale ainda observar os dados referentes ao IDHM ${ }^{4}$, que na Tabela 2 traçam um comparativo entre o Brasil, o Estado do Pará e o município de São Félix do Xingu. Pode-se constatar que o IDH do Brasil apresenta os valores de 0,493 (1991), 0,612 (2000) e 0,727 (2010); um claro indicativo de desenvolvimento nos aspectos fundamentais que compõem o índice como longevidade, educação e renda. Pará e São Félix do Xingu apresentam evolução de maneira inferior ao Brasil, 0,413 (1991), 0.518 (2000) e 0,646 (2010) para o Pará; já São Félix do Xingu, 0,315 (1991), 0,435 (2000) e (0,594).

Tabela 2- IDHM, 1991, 2000, 2010, Brasil, Pará e São Félix do Xingu (PA)

\begin{tabular}{lccc}
\hline & IDHM (1991) & IDHM (2000) & IDHM (2010) \\
\hline BRASIL & 0,493 & 0,612 & 0,727 \\
\hline PARÁ & 0,413 & 0,518 & 0,646 \\
\hline SÃO FÉLIX DO XINGU & 0,315 & 0,435 & 0,594 \\
\hline
\end{tabular}

Fonte: http://atlasbrasil.org.br/2013/, elaborado pelo autor.

Mais preocupante ainda é o dado que se refere à taxa de escolarização no município, apresentando um índice de $77,9 \%$ de escolarização entre os 6 e 14 anos de idade (142ª no Estado, uma das piores do país como um todo), segundo o Censo Demográfico de 2010. O município todo tem apenas 4 escolas de Ensino Médio, segundo dados do INEP para o ano de 2017. Também é alto o índice de mortalidade infantil (13,17 óbitos por mil nascidos vivos em 2014, segundo o DATASUS/Ministério da

4 O IDH é medido a partir de dados de renda per capita, expectativa de vida, educação e saúde, variando de 0 a 1 , sendo que quanto mais próximo de 1 , maior é o desenvolvimento humano. 
Saúde, ocupando a $89^{a}$ posição no Estado), bem como a taxa de esgotamento sanitário adequado (22,5\%, segundo o Censo de 2010 do IBGE, correspondendo à 33a posição no Estado).

Contrastando com os baixos indicadores de desnvolvimento humano, o Produto Interno Bruto de São Félix do Xingu para o ano de 2016 é $016^{\circ}$ maior do Estado do Pará, totalizando $\mathrm{R} \$$ 1.413.761.000,00. O Gráfico 1, apresentado a seguir, demonstra a evolução da participação no PIB de São Félix do Xingu, de 2002 a 2014, destacando-se a participação setorial do PIB da agropecuária (embora também se verifique uma acentuada queda na participação desse setor, caindo de $64 \%$ em 2002 para 43\% em 2014).

Gráfico 1- Evolução da participação setorial no PIB de São Félix do Xingu (PA), 2002 a 2014

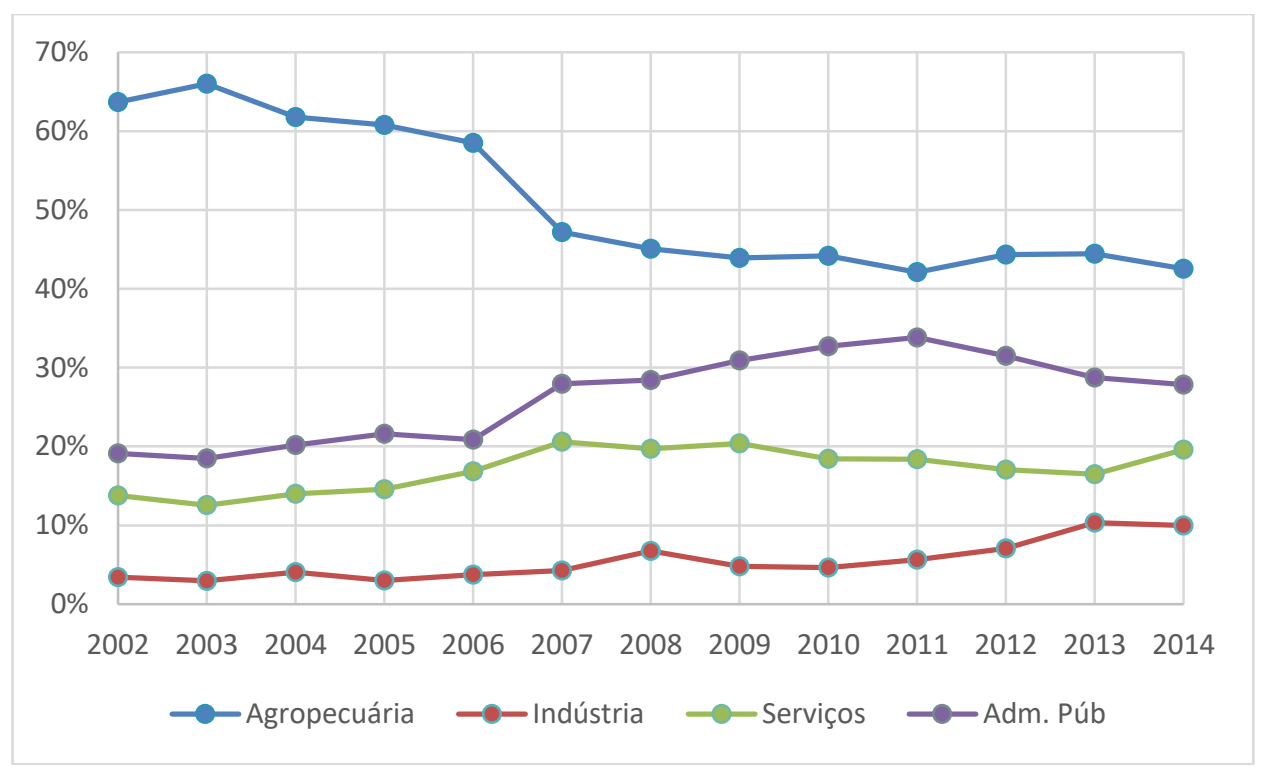

Fonte: Produto Interno Bruto dos Municípios - IBGE (2002-2014).

Possivelmente o processo urbanização, que a partir dos anos 2000 apresenta-se com maior força, explique o crescimento na participação de setores típicos de áreas urbanas como a administração pública e o setor de serviços, que apresentam crescimento significativo nesse período, que acaba por absorver e atrair força de trabalho para área urbana do município de São Félix do Xingu.

\begin{abstract}
A economia da pecuária atrai também outras atividades, embora o encadeamento local a médio e longo prazo seja muito reduzido. Profissionais liberais, pequenos empresários de informática, restaurantes, donos de pousadas, todos esperam uma oportunidade de ficar ricos com o dinheiro que circula na cidade com 0 afluxo de muitos fazendeiros. Porém, todos lamentam que a exploração madeireira tenha sido interrompida, pois essa atividade produzia maior circulação de dinheiro na cidade (CASTRO; MONTEIRO; CASTRO, 2004, p.28).
\end{abstract}

Quanto ao uso do solo no município de São Félix do Xingu, os dados preliminares do Censo Agropecuário de 2017 (IBGE) indicam que 52\% da área total do município é ocupada pela categoria de 
pastagens plantadas em boas condições (dividindo-se em 5.545 estabelecimentos, portanto, 86,9\% de um total de 6376 unidades de produção). Também se destaca, quanto ao uso do solo, a proporção de $38 \%$ da área municipal total correspondente a áreas de florestas naturais destinadas à preservação permanente ou reserva legal. Ainda segundo dados do Censo Agropecuário (2017), a área total dos estabelecimentos agropecuários em SFX é de 2.462.331,128ha.

Gráfico 2 - Distribuição dos estabelecimentos agropecuários por tamanho da propriedade, 2006.

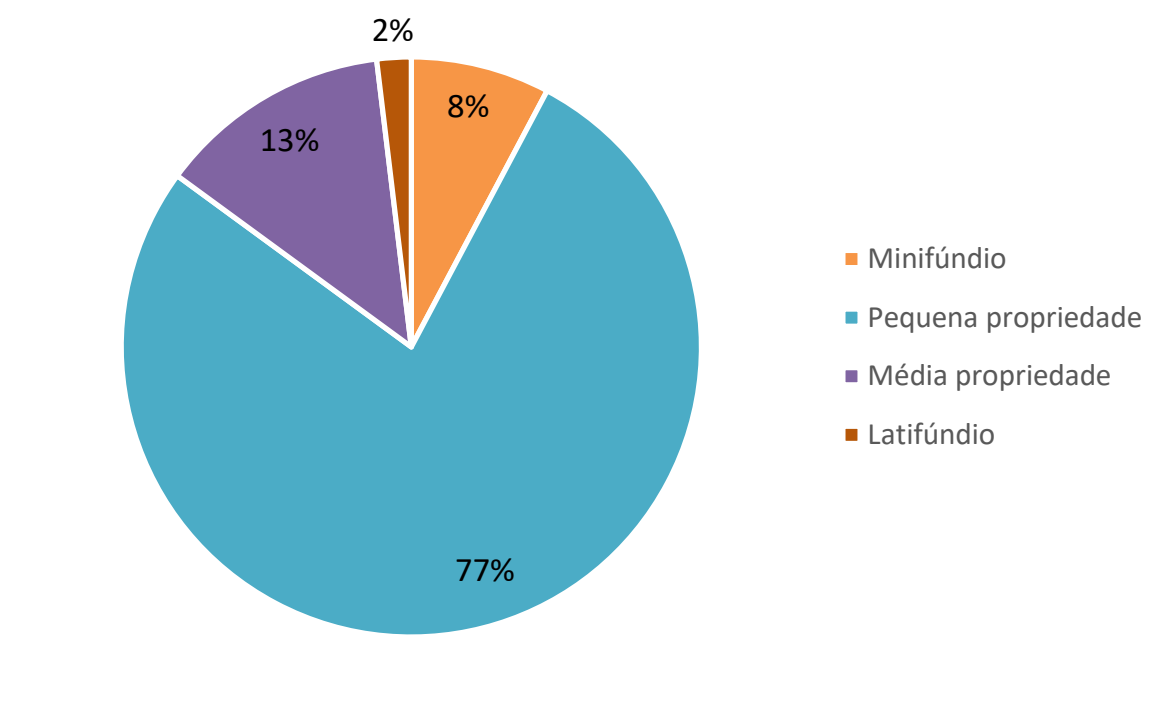

Fonte: Censo agropecuário - Sidra/IBGE (2006).

No gráfico 2 observa-se a distribuição dos estabelecimentos agropecuários por tamanho da propriedade, revelando que a pequena propriedade corresponde à maior parte dos estabelecimentos da agropecuária, cerca $77 \%$, seguida pela média propriedade, 13\%, minifúndio com $7,8 \%$ e o latifúndio que concentra apenas 1,9\% dos estabelecimentos agropecuários em São Félix do Xingu. No que tange à concentração de terras, o Gráfico 3 apresenta a distribuição de terras pelo tamanho da propriedade, permitindo demostrar um dos aspectos mais evidentes da desigualdade social no Brasil: os dados demostram que metade das terras utilizadas para agropecuária em São Félix do Xingu concentram-se no latifúndio, cerca $50,4 \%$, acompanhado da média propriedade com $35,8 \%$ e a pequena propriedade e o minifúndio chegando conjuntamente a $14 \%$ das terras. 
Gráfico 3 - Distribuição de terras por tamanho de propriedade, 2006.

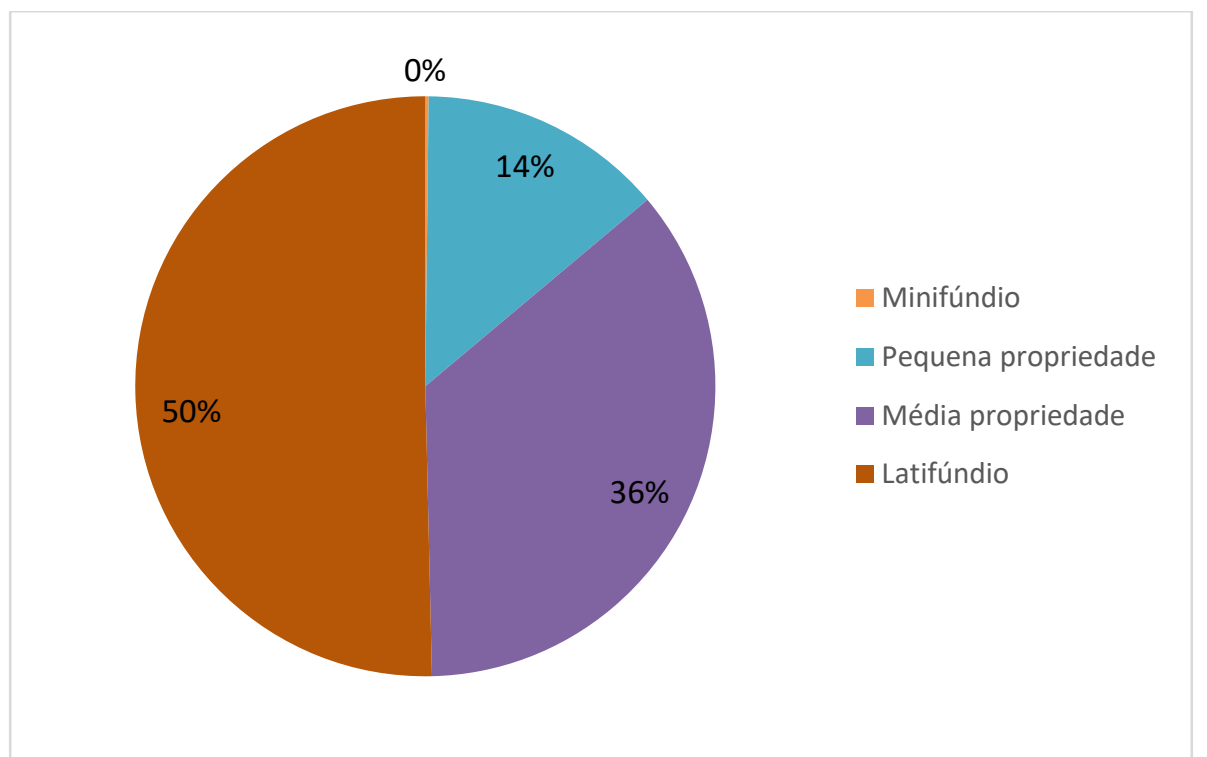

Fonte: Censo agropecuário - Sidra/IBGE (2006).

O Gráfico 4 revela dos dados da distribuição do rebanho por finalidade da criação segundo tamanho da propriedade. Segundo estes dados, podemos notar que a pequena propriedade apresenta cerca $72 \%$ da criação destinada à produção de leite. Na média propriedade a criação de gado para corte passa a ser mais significativa (cerca de $43 \%$ ). Já o latifúndio praticamente não destina sua criação de gado para produção de leite, destinando sua criação para o corte (cerca $34 \%)$ e uso em trabalho, $(27,6 \%)$. Estes dados confirmam que a criação de gado para corte é uma atividade predominantemente realizada em grandes propriedades de terra, aproveitando-se de um investimento relativamente baixo tanto de capital variável quanto de capital constante para obter rentabilidade, enquanto as atividades mais intensivas são realizadas em propriedades menores, com base no trabalho familiar. De fato, o Censo Agropecuário do IBGE (dados preliminares para 2017) aponta que, em todo o município de São Félix do Xingu, foram registrados apenas 1.306 tratores, 206 semeadeiras e 69 adubadeiras ou distribuidoras de calcário.

A pecuária leiteira, portanto, "não é uma atividade procurada pelos grandes produtores. É uma atividade de subsistência que mantém os agricultores familiares em condições de reservar uma pequena poupança e assegurar o auto-consumo" (CASTRO; MONTEIRO; CASTRO, 2004, p.36). Segundo dados da Pesquisa de Produção da Pecuária Municipal, realizada pelo IBGE para o ano de 2017, das 2.240.496 cabeças de gado registradas em São Félix do Xingu, apenas 14.940 correspondiam à categoria de vacas ordenhadas. Ainda no que se refere às diferenças existentes entre os grandes criadores de gado para 
corte e os pequenos produtores de leite, é notável o dado de que, no ano de 2017, um total de 439 estabelecimentos obteve crédito não proveniente de programas governamentais, enquanto as linhas de crédito para o pequeno produtor, como o PRONAF, só alcançaram 121 estabelecimentos. De modo geral, contudo, o acesso a crédito é baixo entre as unidades pesquisadas pelo Censo Agropecuário do IBGE em São Félix do Xingu.

Gráfico 4- Distribuição do rebanho bovino por finalidade da criação, segundo tamanho da propriedade, 2006, São Félix do Xingu (PA).

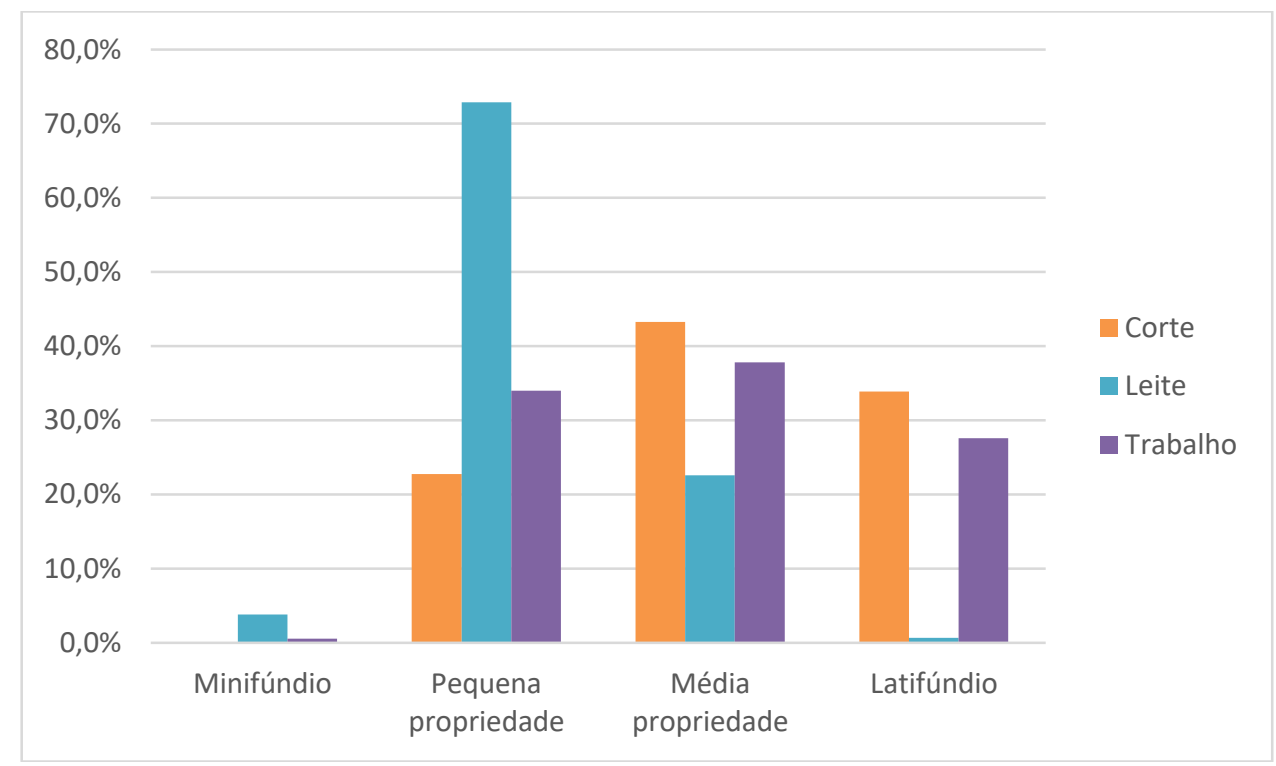

Fonte: Censo agropecuária - Sidra/IBGE (2006).

O Gráfico 5, por sua vez, apresenta a população ocupada segundo setor de atividade econômica, revelando que cerca de $51 \%$, da população ocupada encontra-se no setor de serviços, seguida pelo setor agropecuário, com $46,2 \%$, sendo o setor industrial o com menor percentual, cerca $2,3 \%$ da população ocupada. Importante salientar que o setor de serviços apresenta esse dinamismo pela própria característica urbana desse setor, e com o crescimento da população urbana, esse setor acaba por utilizar grande parte da força de trabalho disponível. O setor agropecuário possui características próprias de utilização da força de trabalho, como a sazonalidade da produção, uso cada vez maior de tecnologia voltadas para aumentar a produtividade, e no caso da pecuária, a utilização de pouca força de trabalho na criação do gado. 
Gráfico 5 - Participação da Pop. Ocupada por setor de atividade econômica.

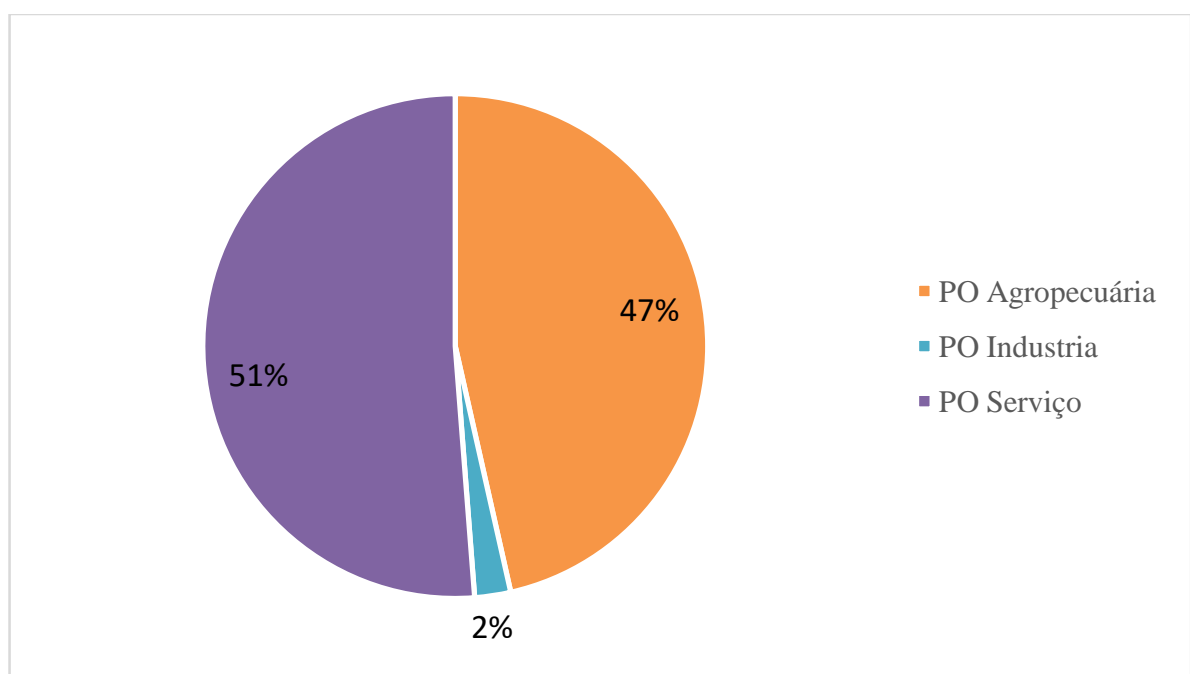

Fonte: Censo demográfico - Sidra/IBGE (2010).

gráfico 6 demostra a força de trabalho ocupada segundo a jornada de trabalho na agropecuária, sendo que as faixas de horas trabalhadas que apresentam os maiores percentuais são de 45 a 48 horas, $32 \%$, e de 49 horas ou mais, 23\%. No que tange à contribuição com a previdência social, $85 \%$ da força de trabalho ocupada não realiza contribuição à previdência, demonstrando-se com isso a precariedade do trabalho rural nas áreas de predomínio da bovinocultura para corte.

Gráfico 6 - Características da Força de Trabalho Ocupada (FTO) no setor Agropecuário, segundo faixas de horas, São Félix do Xingu (PA)

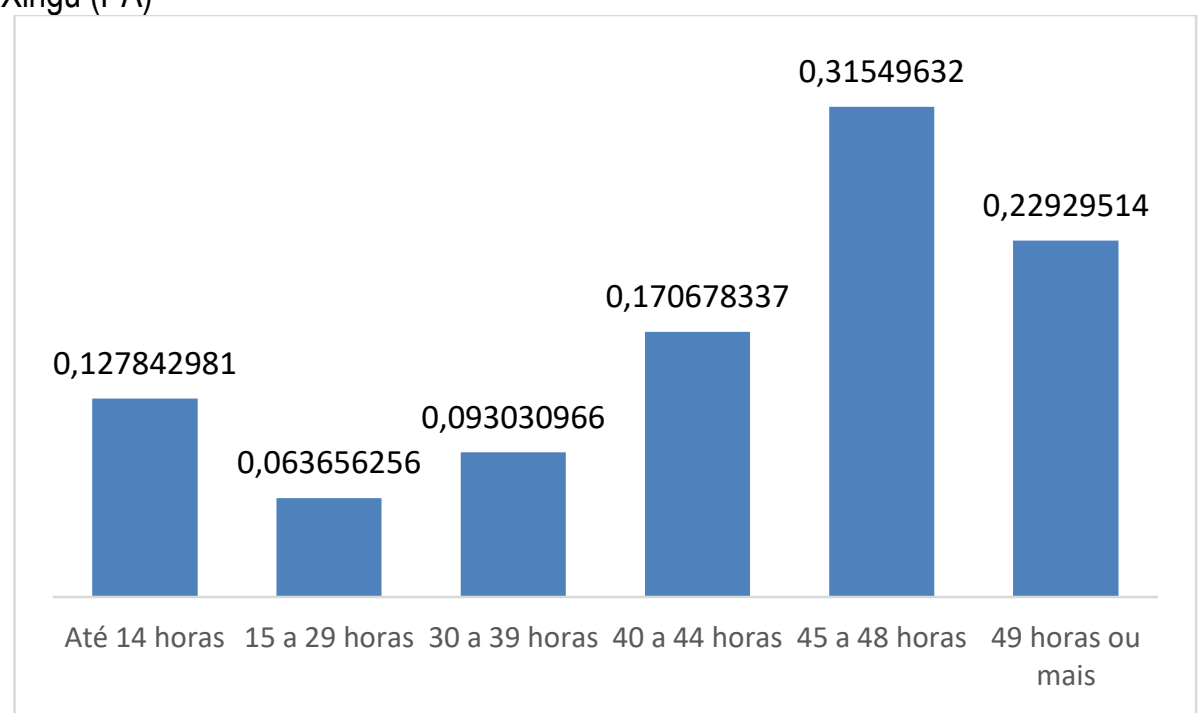

Fonte: Censo demográfico - Sidra/IBGE (2010).

A força de trabalho ocupada no setor agropecuário acaba por se caracterizar por ser uma força de trabalho bastante precarizada, dado que apontamos um perfil de um trabalhador jovem, com baixo 
nível de instrução formal, que trabalha uma jornada de trabalho que excessiva e que não contribui para previdência; o que o coloca em uma condição de muita vulnerabilidade social. Contudo, cabe notar que, no histórico da luta pela terra no sudeste do Pará, parte significativa da população camponesa resistiu à proletarização forçada e ao trabalho penoso e mal remunerado do peão. No Gráfico 7 apresentamos a posição na ocupação no setor agropecuário em São Félix do Xingu, identificando que os empregados (30\%) são o extrato da população trabalhadora rural assalariada; contudo percebemos um percentual significativo dos trabalhadores por conta própria (38\%), bem como o dos trabalhadores que produzem para o próprio consumo (TPPC), indicando, com isso, uma reprodução do campesinato que contrasta com a voracidade dos grandes empreendimentos agropecuários por terra e por trabalho barato e descartável na região.

Gráfico 7 - Posição na ocupação no setor Agropecuária, São Félix do Xingu (PA).

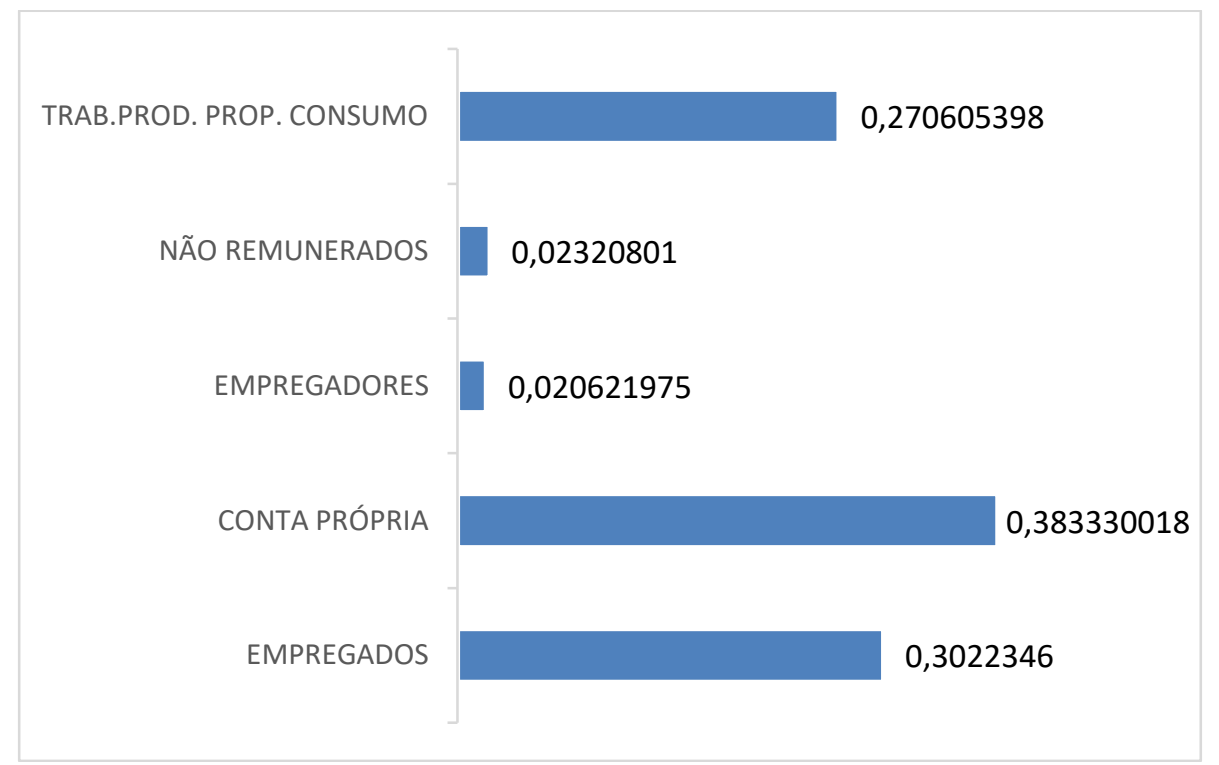

Fonte: Censo agropecuário - Sidra//BGE (2006).

O município de São Félix do Xingu tradicionalmente detinha a maioria da sua população em áreas rurais, consequentemente a organização dessa população que é oriunda em grande parte de migrantes camponeses que desde a década de 1970 ocuparam a região. Concomitantemente, grandes empresários e grupos econômicos se instalaram com apoio e patrocínio do Estado, transformando a região em uma arena de conflitos fundiários. Desde o período de redemocratização do país o Estado busca, através principalmente do Incra, atender a demandas levantadas por essas populações de 
camponesas, que buscaram se organizar em movimentos sociais de luta pelo direito a terra como 0 Movimento dos Sem-Terra (MST).

Na tabela 3 apresentamos a relação de projetos de assentamentos para reforma agrária em São Félix do Xingu, de 1995 a 2012. Foram criados 18 projetos de assentamentos com capacidade de atender a 4.826 famílias, totalizando uma área 325.642 ha. Contudo, apesar de ser uma política importante de acesso aterra a várias famílias de trabalhadores camponeses o excesso de burocracia e a falta de investimento e apoio político colaboram para que desde 2012 não tenham sido criados novos assentamentos e mesmo os assentamentos já criados não tem sua capacidade totalmente ocupadas por famílias, apresentando um saldo de 933 lotes que poderiam ser ocupados.

Tabela 3 - Projetos de Assentamentos em São Félix do Xingu, 1995 a 2012.

\begin{tabular}{|c|c|c|c|c|}
\hline Nome PA & Capacidade & Famílias assentadas & Área PA & DT. Criação \\
\hline PA TANCREDO NEVES & 430 & 369 & 17.165 & 10/01/1995 \\
\hline PA COLONIA S. JOSE DO XINGU & 850 & 844 & 39.418 & 10/01/1995 \\
\hline PA SUDOESTE & 550 & 451 & 29.218 & 27/12/1996 \\
\hline PA LINDOESTE & 495 & 136 & 11.778 & 27/05/1998 \\
\hline PA SÃO SEBASTIÃO DO XINGÚ & 259 & 259 & 10.800 & 05/03/1999 \\
\hline PA RIO PARA & 186 & 160 & 4.279 & $15 / 12 / 2000$ \\
\hline PA RIO CINZA & 120 & 110 & 6.064 & $15 / 12 / 2000$ \\
\hline PA RIO NEGRO & 80 & 75 & 3.906 & $15 / 12 / 2000$ \\
\hline PA ARAPARI & 250 & 148 & 14.292 & $15 / 12 / 2000$ \\
\hline PA ANTARES & 130 & 89 & 7.035 & 07/10/2004 \\
\hline PA SUMAUMA II & 100 & 98 & 5.120 & 09/09/2005 \\
\hline PA SANTIAGO & 90 & 89 & 5.227 & $10 / 10 / 2005$ \\
\hline PA OESTE & 52 & 52 & 2.945 & $01 / 11 / 2005$ \\
\hline PA CENTRO DOS MARANHENSES & 44 & 35 & 2.114 & $05 / 12 / 2005$ \\
\hline PA COLONIA MURAD & 38 & 10 & 2.985 & $02 / 10 / 2006$ \\
\hline PA POMBAL & 540 & 455 & 120.000 & $19 / 12 / 2006$ \\
\hline PA BARRA MANSA & 200 & 102 & 18.085 & $19 / 12 / 2007$ \\
\hline PA BELAUTO & 412 & 411 & 25.211 & $18 / 07 / 2012$ \\
\hline TOTAL & 4.826 & 3.893 & 325.642 & - \\
\hline
\end{tabular}

Fonte: Instituto Nacional de Reforma Agrária -INCRA (1995-2012).

Para encerrar esta análise sobre a concentração fundiária e sobre o mundo do trabalho no município de São Félix do Xingu, cabe mencionar que esta é uma das regiões de maior incidência de 
trabalho escravo no Brasil, segundo a Comissão Pastoral da Terra. O estado do Pará é o que aparece como principal foco desse trabalho escravo com $48 \%$ dos trabalhadores libertados no período, seguido por Mato Grosso com 22\%, Maranhão e Tocantins com 12\% e 11\%. O emprego de trabalhadores sob a promessa de trabalho assalariado em empreendimentos agropecuários acaba por ser um elemento de mobilização de trabalhadores de origem camponesa que por sua vez acabam por ser escravizados na Amazônia. Esses trabalhadores são usualmente recrutados por intermediários que buscam essa força de trabalho em áreas onde a pobreza e a dificuldade de subsistir em uma pequena propriedade acabam por vulnerabilizar estes trabalhadores, tornando-os sujeitos a trabalhar em fazendas que em, sua maioria, se localizam em áreas remotas de difícil acesso, o que acaba por dificultar as eventuais tentativas de fugas e bem como o trabalho de fiscalização realizado pelas Delegacias do Trabalho. Se buscarmos estabelecer uma espécie de perfil desse trabalhador escravo que empregado na agropecuária em São Félix do Xingu, ele é pobre de origem camponesa, normalmente migrante, do sexo masculino, entre 18 a 44 anos, com baixo nível de instrução, que é principalmente empregado na atividade de peão desses empreendimentos. Identificamos o fenômeno do trabalho escravo em São Félix do Xingu não como uma aberração ao modo de produção capitalista; entendemos que esse fenômeno evidencia exatamente a funcionalidade de se manter relações de trabalho não tipicamente capitalistas para viabilizar reprodução ampliada do capital na Amazônia.

\section{CONSIDERAÇÕES FINAIS}

Este trabalho buscou demonstrar como a atividade pecuária, tida como um dos grandes destaques do agronegócio no Brasil, na verdade veio servindo como meio para a apropriação privada de terras públicas no Brasil, gerando conflitos sociais e violência no campo, bem como provocando problemas ambientais, notadamente a remoção da cobertura vegetal de largas porções da floresta Amazônica, em benefício do grande capital rentista típico da formação social e econômica brasileira.

Tomando como referência o município de São Félix do Xingu, localizado na mesorregião Sudeste do Estado do Pará, pudemos primeiramente constatar, por meio de pesquisa bibliográfica, que a geografia histórica da fronteira na Amazônia Oriental foi permeada pela ação do Estado autoritário durante o Regime Militar no Brasil que, por meio de incentivos fiscais e crédito bancário, fomentou a ação de grileiros e a finalidade puramente especulativa da propriedade da terra. Esta foi a raiz do quadro de profunda concentração fundiária verificada não só nesta área de estudo, mas no território nacional como um todo. 
Embora a atividade de criação de gado de corte se ponha atualmente como um setor altamente competitivo do agronegócio no Brasil, com importante participação na pauta de exportações nacional, essa modernidade tem como contrapartida uma intensa precarização do trabalho, especialmente o dos peões que participam como trabalhadores temporários altamente descartáveis do ponto de vista do grande capital. Contudo, verifica-se a resistência da luta camponesa neste território, a qual se notabiliza pela quantidade de assentados que sobrevivem do trabalho familiar no município de São Félix do Xingu, contrapondo-se à violência impetrada pelo latifúndio no Brasil.

\section{REFERÊNCIAS BIBLIOGRAFICAS}

BECKER, Bertha K. As amazônias de Bertha K. Becker: ensaios sobre geografia e sociedade na região amazônica. Rio de Janeiro: Garamond, 2015.

CARVALHO, André Cutrim. Expansão da fronteira agropecuária e a dinâmica do desmatamento florestal na Amazônia paraense. (Tese de Doutorado). Campinas: UNICAMP, 2012. CASTRO, Edna Ramos; MONTEIRO, Raimunda; CASTRO, Carlos Potiara. Atores sociais na fronteira mais avançada do Pará: São Félix do Xingu e Terra do Meio. Belém: Papers no NAEA, $\mathrm{n}^{\circ} 180,2004$.

CORREA, Eduardo Simões et. al. Sistema e Custo de Produção de Gado de Corte no Estado do Pará - Região de Paragominas. Campo Grande (MS): EMBRAPA, 2015.

DIAS-FILHO, Moacyr Bernardino. Produção de bovinos a pasto na fronteira agrícola. Belém, PA: Embrapa Amazônia Oriental, 2010.

IANNI, Otávio. A luta pela terra: história social da terra e da luta pela terra numa área da Amazônia. Coleção Sociologia brasileira. v.8. Petrópolis: Vozes, 1981.

IANNI, Otávio. Ditadura e Agricultura: o desenvolvimento do capitalismo na Amazônia: 1964-1978. Ed. Civilização brasileira, 1979.

INTITUTO NACIONAL DE COLONIZAÇÃO E REFORMA AGRÁRIA (INCRA). Relatório

Assentamentos de Trabalhadores (as) Rurais - Números Oficiais. Diretoria de Obtenção de Terras e Implementação de Projetos de Assentamentos - DT. Disponível em: <www.icra.gov.br>. Acesso em 12 set. 2020.

INSTITUTO BRASILEIRO DE GEOGRAFIA E ESTATÍSTICA (IBGE). Sistema IBGE de Recuperação Automática - SIDRA. Censo Agropecuário 2006. Disponível em: $<$ https://sidra.ibge.gov.br/pesquisa/censo-agropecuario/censo-agropecuario-2006>. Acesso em 10 agosto de 2020.

INSTITUTO BRASILEIRO DE GEOGRAFIA E ESTATÍSTICA (IBGE). Sistema IBGE de Recuperação Automática - SIDRA. Censo Demográfico 2010. Disponível em: <https://sidra.ibge.gov.br/pesquisa/censo-agropecuario/censo-demografico-2010>. Acesso em 10 agosto de 2020.

INSTITUTO BRASILEIRO DE GEOGRAFIA E ESTATÍSTICA (IBGE). Sistema IBGE de Recuperação Automática - SIDRA. Sistema de Contas Nacionais. Disponível em: $<$ https://sidra.ibge.gov.br/pesquisa/pib-munic/tabelas>. Acesso em 10 agosto de 2020. LEAL, Aluizio Lins. Sinopse Histórica da Amazônia. In: TRINDADE, José R.; MARQUES, Gilberto (org). In: Revista de Estudos Paraenses, edição especial-IDESP. Belém: IDESP, 2010. 
MICHELOTTI, Fernando. "Luta pela terra e assentamentos no sudeste do Pará". In: Antropolítica. Niterói, n. 26, p. 245-266, $1^{\circ}$ sem. 2009. Disponível em:

https://s3.amazonaws.com/academia.edu.documents/30869274/revista_antropolitica_26.pdf?AWSAcce ssKeyld=AKIAIWOWYYGZ2Y53UL3A\&Expires=1552065873\&Signature=ePji7YeBBoMmFpBsPZu16N kpdmQ\%3D\&response-content-

disposition=inline\%3B\%20filename\%3DQuando_tecnologia_lei_e_familia_converge.pdf\#page=135. Último acesso em 10/03/2019.

MARTINS, José de Sousa. 0 cativeiro da terra. - $9^{\mathrm{a}}$ ed., $2^{\mathrm{a}}$ reimpressão - São Paulo: Contexto, 2015. $282 \mathrm{p}$.

MARTINS, José de Sousa. Fronteira: a degradação do Outro nos confins do humano. - $2^{\mathrm{a}}$ ed., $1^{\mathrm{a}}$ reimpressão - São Paulo: Contexto, 2012. 187 p.

OLIVEIRA, Ariovaldo Umbelino. Modo de Produção Capitalista, Agricultura e Reforma Agrária. São Paulo: FFLCH, 2007, 184p.

OLIVEIRA, Ariovaldo Umbelino de. Amazônia: monopólio, expropriação e conflitos. Campinas-SP: Papirus, 1993.

OLIVEIRA, Ariovaldo Umbelino. Modo Capitalista de Produção e Agricultura. São Paulo: Ática, 1986. V. 01. 88p.

PROGRAMA DAS NAÇÕES UNIDAS - PNUD. Atlas do desenvolvimento humano. Disponível em: $<w w w . a t l a s b r a s i l . o r g, b r>$. Acesso em 10 de set. 2020.

SCHMINK, Marianne; WOOD, Charles H. Conflitos Sociais e a Formação da Amazônia. Belém: ed. ufpa, 2012. $496 \mathrm{p}$.

VELHO, Octavio Guilherme. Capitalismo Autoritário e Campesinato. São Paulo: ed. DIFEL, 1974. $261 \mathrm{p}$. 


\title{
EXPLORAÇÃO DA TERRA E DO TRABALHO NA FRONTEIRA AGROPECUÁRIA DA AMAZÔNIA ORIENTAL: O CASO DE SÃO FÉLIX DO XINGU (PA)
}

\section{RESUMO}

O objetivo central deste trabalho é o de dimensionar o nível de exploração da terra e do trabalho no município de São Félix do Xingu, em contraposição com a competitividade internacional alcançada pelo setor. $O$ procedimento metodológico de investigação desta pesquisa consiste em um levantamento bibliográfico acerca da expansão da fronteira agropecuária na Amazônia, bem como em um levantamento de dados estatísticos sobre a estrutura fundiária e as relações de trabalho na área de estudos selecionada. Argumentaremos no sentido de propor que a pecuária de corte para exportação é uma atividade que consumiu um enorme montante de recursos financeiros públicos para ser implantada e, embora esteja caminhado no sentido de se aprimorar tecnicamente, tendo se tornado um importante setor do agronegócio brasileiro, só pôde alcançar esta relevância ao expropriar populações tradicionais e concentrar terras, além de criar trabalho precarizado em massa, gerando poucos empregos assalariados formais e bem remunerados.

Palavras-chave: fronteira agropecuária; Amazônia Oriental; concentração fundiária; trabalho.

\begin{abstract}
The main objective of this work is to measure the level of land and labor exploitation in the municipality of São Félix do Xingu, in contrast to the international competitiveness achieved by the sector. The methodological investigation procedure of this research consists of a bibliographic survey about the expansion of the agricultural frontier in the Amazon, as well as a survey of statistical data on the land tenure structure and labor relations in the selected study area. We will argue in order to propose that beef cattle for export is an activity that consumed a huge amount of public financial resources to be implemented and, although it is moving towards technical improvement, having become an important sector of Brazilian agribusiness, only it was able to achieve this relevance by expropriating traditional populations and concentrating land, in addition to creating precarious work en masse, generating few formal and well-paid wage jobs.
\end{abstract}

Key words: frontier; Oriental Amazon; land concentration; labour.

JEL: R1, R23 e R52. 